\title{
Symposium review: Features of Staphylococcus aureus mastitis pathogenesis that guide vaccine development strategies*
}

\author{
Julie Côté-Gravel and François Malouin† \\ Centre d'Étude et de Valorisation de la Diversité Microbienne (CEVDM), Département de biologie, Faculté des sciences, \\ Université de Sherbrooke, Sherbrooke, Canada, J1K 2R1
}

\section{ABSTRACT}

Bovine mastitis affects animal health and welfare and milk production and quality, and it challenges the economic success of dairy farms. Staphylococcus aureus is one of the most commonly found pathogens in clinical mastitis but it also causes subclinical, persistent, and difficult-to-treat intramammary infections. Because of the failure of conventional antibiotic treatments and increasing pressure and concern from experts and consumers over the use of antibiotics in the dairy industry, many attempts have been made over the years to develop a vaccine for the prevention and control of Staph. aureus intramammary infections. Still, no commercially available vaccine formulation demonstrates sufficient protection and cost-effective potential. Multiple factors account for the lack of protection, including inadequate vaccine targets, high diversity among mastitis-provoking strains, cow-to-cow variation in immune response, and a failure to elicit an immune response that is appropriate for protection against a highly complex pathogen. The purpose of this review is to summarize key concepts related to the pathogenesis of Staph. aureus, and its interaction with the host, as well as to describe recent vaccine development strategies for prevention and control of Staph. aureus mastitis.

Key words: bovine mastitis, Staphylococcus aureus, pathogenesis, vaccine

\section{INTRODUCTION}

For decades now, an important amount of significant knowledge and research data have been collected about mastitis in dairy cows. This research has been driven by the increasing need to find effective ways to detect,

Received June 24, 2018.

Accepted October 7, 2018.

*Presented as part of the Joint ADSA/NMC Symposium: Advances in Mammary Health and Immunology at the ADSA Annual Meeting, Knoxville, Tennessee, June 2018.

$\dagger$ †orresponding author: francois.malouin@usherbrooke.ca control, and prevent the disease. Although mastitis can occur following udder trauma or some physiological disorders, it is most often due to bacterial IMI. Despite great progress in our comprehension of host-pathogen interactions, the use of new farm management practices, and the development of novel treatment and prevention tools, bovine mastitis is still the most common disease with the greatest economic impact for the dairy industry (Bar et al., 2008; Ruegg, 2017; Aghamohammadi et al., 2018).

An IMI can manifest in clinical forms of variable threat levels, according to the severity of the symptoms. An IMI can also manifest with a total absence of visible, macroscopic signs of disease, in the form of a subclinical infection. The clinical or nonclinical character of mastitis is mainly influenced by the genus and species of the responsible pathogen (Rainard and Riollet, 2006; Zadoks et al., 2011). Subclinical IMI are responsible for most of the economic problem associated with mastitis (Shim et al., 2004; Petrovski et al., 2006). The vast majority of IMI cases in herds occurs in the subclinical form, and Staphylococcus aureus is an important contributor to such subclinical IMI (Reyher et al., 2011).

Treatment and prevention of Staph. aureus IMI using antibiotic therapy is difficult. Reported cure rates for Staph. aureus mastitis have been shown to vary considerably and seem to depend on many factors at the herd, cow, and bacterial levels, such as herd transmission rates, cow parity, level of SCC, and the genetic background and phenotypic traits of Staph. aureus isolates, including their level of biofilm production (Barkema et al., 2006; Ster et al., 2017). Moreover, persistence of the pathogen in the gland can last the lifetime of the animal (Sutra and Poutrel, 1994). Early treatment of new infections can be effective; however, chronically infected cows generally respond poorly to treatment during lactation. In fact, conventional approved treatments rarely achieve a cure rate greater than 20 to $50 \%$ and, most of the time, there is a relapse of infections during subsequent lactations, demonstrating that the pathogen is still present or that a new infection can 
arise easily (Dinsmore, 2002; Roy and Keefe, 2012; Ster et al., 2017). In general, extended antibiotherapies or treating dry cows are strategies with a higher probability of cure (Roy and Keefe, 2012; Rainard et al., 2018). There are also risks associated with antibiotherapy, and the public pressure to reduce antibiotic use in animal production is an important incentive to find efficient nonantibiotic control measures for this disease. Of particular concern are the spread of antibiotic resistance genes by horizontal transfer (Li and Zhao, 2018) and the emergence of livestock-associated methicillin-resistant Staph. aureus (MRSA) strains that can be transmitted from cows to humans (García-Álvarez et al., 2011; Holmes and Zadoks, 2011).

Thus, preventing infection through vaccination would be a judicious choice for the control of Staph. aureus IMI. Ideally, vaccination would eliminate the reservoir of infection in herds, reduce the incidence of new cases of IMI, and improve milk production and quality. Unfortunately, the versatility of the pathogen, which produces a variety of virulence factors, its numerous ways of camouflaging itself from the immune system, and the diversity of strains that can actually cause the disease have prevented successful vaccine development in recent decades (Ismail, 2017; Rainard et al., 2018). However, advances made in the understanding of Staph. aureus pathogenesis and on how the host immune system operates during Staph. aureus infections open the door to further progress. Figure 1 summarizes host-Staph. aureus interactions and provides an overview of the topics of discussion reviewed here, notably the complexity of Staph. aureus pathogenesis and some vaccine development strategies.

\section{EFFECT OF STAPH. AUREUS IMI}

Several families of bacteria can cause mastitis in dairy cows. Overall, staphylococci (Staph. aureus and non-aureus staphylococci) are the most common mastitis-causing agents, followed by streptococci and Escherichia coli (Contreras and Rodriguez, 2011; Reyher et al., 2011; Condas et al., 2017). Pathogens causing IMI can be broadly classified into 2 epidemiological categories: contagious bacteria and environmental bacteria. Coliform bacteria are often described as noncontagious environmental pathogens associated with strong clinical symptoms (Hogan and Smith, 2003). On the other hand, contagious pathogens are mostly transmitted during the milking process and a reservoir of such bacteria can exist within herds. As such, there is real potential that these pathogens cause outbreaks with high incidence rates (Murai et al., 2014). The contagious pathogens include Staph. aureus, non-aureus staphylococci, Streptococcus spp. Mycoplasma spp., and
Corynebacterium bovis. Staphylococcus aureus is one of the most important causes of the disease worldwide and the most commonly isolated pathogen in the context of both clinical and subclinical IMI in Canada (Reyher et al., 2011; Naqvi et al., 2018). Milk from infected cows is the main source of transmission of microorganisms from infected cows to their healthy neighbors and this mostly occurs during milking (Olde Riekerink et al., 2008). There is a strong link between transmission of the disease and management quality of the milking facility, which includes teat disinfection procedures and the general cleanliness of the milking equipment used.

Subclinical IMI represent a specific concern because they can stay unnoticed for some time, contribute to the infectious reservoir, and thus increase the risk of transmission. Subclinical IMI can be suspected following an important increase in SCC in milk and confirmed by bacteriology or molecular tests that detect the presence of microorganisms in milk. Staphylococcus aureus can alter various milk constituents through production of various hydrolytic enzymes and, consequently, reduce the yield and quality of milk products. The total economic losses associated with Staph. aureus clinical and subclinical IMI result from the decrease in milk production and quality, the costs of antibiotic treatments and veterinary fees, and the withdrawal period of cows treated with antibiotics (Halasa et al., 2007; Olde Riekerink et al., 2008; Aghamohammadi et al., 2018).

\section{PATHOGENESIS OF STAPH. AUREUS IMI}

Several important elements are involved in the virulence of Staph. aureus that allow the pathogen to adapt to the mammary gland environment. The pathogenesis of Staph. aureus in bovine mastitis has been detailed in several reports over the years (Sutra and Poutrel, 1994; Middleton, 2008; Rainard et al., 2018), so we will summarize here some of the key steps from which vaccine targets can be extrapolated.

Three specific phases are involved in the Staph. aureus infection process: (1) adhesion to host cell and extracellular matrix, (2) invasion or penetration into tissues and cells, and (3) evasion of the host immune system (Middleton, 2008). This process is associated with the differential expression of a variety of virulence factors at the different stages of infection. In Staph. aureus, the expression of virulence factors is under the control of global regulators such as Agr (accessory gene regulator) and the alternative transcriptional sigma factor SigB (Novick and Geisinger, 2008).

The SigB factor is involved in the response to different stresses and promotes the expression of adhesins and biofilm formation for colonization (Horsburgh et al., 


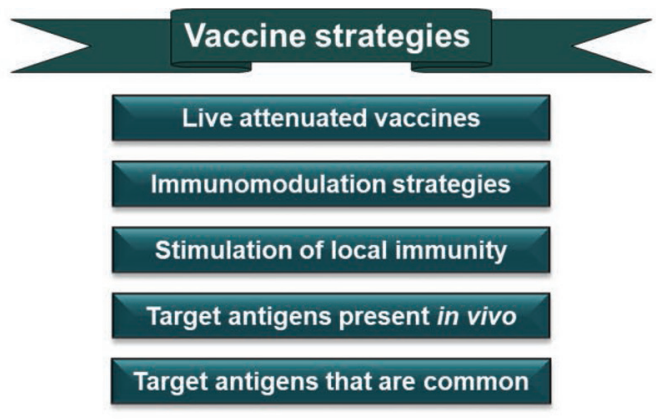

Challenges of $S$. aureus IMI


lymphocytes
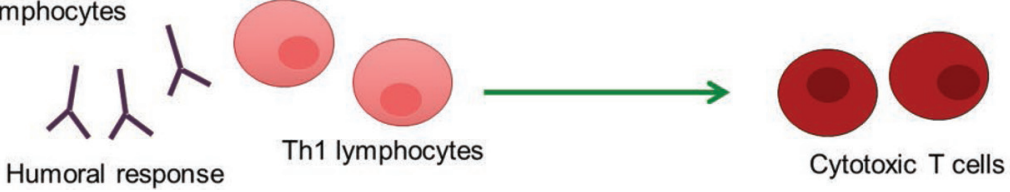

Humoral response

Figure 1. Host-pathogen interactions occurring in Staphylococcus aureus bovine IMI and associated challenges for vaccine development. The pathogenesis of Staph. aureus is complex, and this bacterium produces several virulence factors that are used for colonization and to escape and modulate the immune system for persistence in the host. One of the challenges in tackling Staph. aureus is that the strains that can cause mastitis are diverse and differ in the expression of virulence factors and cell components during IMI, which makes selection of antigens for the development of a vaccine difficult. In addition, through point mutations, highly virulent Staph. aureus (bright yellow cells) can adopt a slowgrowing phenotype known as "small-colony variants" (SCV; pale yellow cells); SCV are well adapted for long-term persistence in tissues with an improved ability for biofilm formation and internalization into host cells. Biofilm and intracellular living can promote subclinical and chronic infections by protecting Staph. aureus from the humoral immune response, antibiotics, and the action of host antimicrobial peptides (crossed red arrows). If such selective pressures for the SCV phenotype are removed, the normal phenotype can be selected back (2-headed black arrow) by its ability to rapidly multiply. Although Staph. aureus of the normal phenotype can promote clinical mastitis, superantigen toxins and other mechanisms that are not entirely elucidated grant Staph. aureus the capacity to dampen or modulate the inflammatory response. Staphylococcus aureus can also counteract opsonization, phagocytosis, and cytotoxic killing by neutrophils through the action of its cytotoxic leukocidin LukMF'. An important challenge for vaccine development will be to elicit an efficient immune response, with mammary-gland localized effectors, and with a strong cell-mediated T-helper (Th)17/Th1 component that will help to neutralize Staph. aureus persistence and immune evasion strategies (see text for details on current scientific knowledge). Green arrows denote activation or cooperation, red arrows are antagonistic effects and black arrows represent a change of status.

2002). In contrast, the Agr locus allows transition from the colonization phase to the invasive phase according to a quorum-sensing mechanism (Novick and Geisinger, 2008). When the bacterial cell density increases, Agr decreases the production of surface adhesion proteins; increases the expression of hydrolytic enzymes, exotoxins, and other aggressive virulence factors; and helps detachment from biofilms (Otto, 2013). More specifically, as the bacterial cell density increases, a secreted auto-inducing peptide (AIP), resulting from the coordinated activity of $\mathrm{AgrD}$ and $\mathrm{AgrB}$, accumulates in the extracellular milieu and eventually reaches a critical concentration to act on the 2-component system AgrC and AgrA to allow expression of a regulatory RNA (RNAIII) that is able to significantly reduce surface protein expression (Novick and Geisinger, 2008). The RNAIII regulator acts directly at the translational level by repressing adhesins as well as rot (repressor of tox- 
ins) mRNA, and the latter is, in contrast, a repressor of exotoxin synthesis and activator of adhesin synthesis (Boisset et al., 2007). Furthermore, RNAIII permits the translation of hla mRNA to allow production of the well-known Staph. aureus $\alpha$-hemolysin, which can lyse several host cell types.

The dynamic regulation of virulence factors orchestrated by the Agr system and other regulators modulates the different phases of Staph. aureus IMI. The teat canal represents an important physical barrier that Staph. aureus encounters during milking before it is able to spread to the entire mammary gland (Rainard and Riollet, 2006). Following this intrusion, the first step in the colonization of the mammary gland is bacterial adhesion to the host epithelial cells and their extracellular matrix. This attachment allows the bacteria to resist evacuation from the pressure of the milk flux. Staphylococcus aureus expresses many virulence factors that are involved in adhesion, including fibronectin (FnBP), fibrinogen (FgBP) and collagen (CNA) binding proteins, as well as clumping factors (Clf) A and B, and teichoic acids (Brouillette et al., 2003; Mitchell et al., 2008; Middleton et al., 2009). Many such factors are known as MSCRAMM (microbial surface components recognizing adhesive matrix molecules). Biofilm formation is also important in the colonization phase (Otto, 2013). A biofilm is a self-produced extracellular polymeric matrix that can protect the community of bacteria against the action of antibiotics and host immune responses (Hathroubi et al., 2017). After this adhesion phase, Staph. aureus synthesizes and secretes factors that allow the invasion, penetration, and destruction of the mammary tissue, including several exotoxins (hemolysins and leukocidins) and various hydrolytic enzymes such as proteases, coagulase, lipases, and hyaluronidases (Middleton, 2008; Suriyaphol et al., 2009). The hemolysins and exoenzymes are implicated in the degradation of the epithelium of the cistern, duct, and alveoli. These microlesions in the mammary gland tissue are responsible for the reduction of milk production, even in the case of subclinical mastitis, when the infection remains unapparent.

Finally, Staph. aureus produces a range of factors that allow it to escape but also modulate the host immune system. The efficacy of the host immune system can be impaired by Staph. aureus superantigen toxins (Wang et al., 2009), protein A, the polysaccharide capsule, biofilm formation, and the invasion/persistence strategy within host phagocytes as well as nonprofessional phagocytic cells (Middleton, 2008). More particularly, resistance against the action of circulating neutrophils and macrophages, which are the main actors in the immunity in the mammary gland, is believed to be an important factor in the pathogenicity of Staph. aureus. Indeed, Staph. aureus has the ability to directly counteract opsonization, phagocytosis, and cytotoxic killing. Of particular interest is the leukocidin LukMF', a bicomponent toxin specifically found in clonal lineages of Staph. aureus that are associated with bovine mastitis (Vrieling et al., 2015). The LukMF' leukocidin has an AA sequence closely related to that of the human-associated Panton-Valentine leukocidin (PVL; LukS-PV) and LukED and was shown to kill bovine migrating neutrophils through recognition of the CCR1 cell surface receptor with very high specificity and efficacy. It was also established that LukMF' is expressed in vivo during mastitis, although strain-to-strain disparity in expression levels has been reported (Vrieling et al., 2016). In the same study, the severity of mastitis clinical symptoms in experimentally infected cows was correlated with the in vivo expression level of LukMF' in milk. Likewise, a very recent genotypic and phenotypic analysis of clinical isolates from farms in the Netherlands found that Staph. aureus strains producing both high and low levels of LukMF' can be found in mastitis samples, of which $22 \%$ of the leukocidin-positive Staph. aureus isolates displayed a 10-fold higher LukMF' production than the average of the low-producing strains (Hoekstra et al., 2018). These high-producing isolates were cultured significantly more frequently from clinical than subclinical mastitis cases and all belonged to the same Staphylococcus aureus protein A (spa) type (t543).

\section{DIVERSITY OF STAPH. AUREUS STRAINS THAT CAUSE MASTITIS}

\section{Staph. aureus Lineages}

The immense diversity of strains capable of causing mastitis is a major obstacle in the development of an effective vaccine. Further disparity is present in the phenotypic aspects and the genomic presence of virulence genes among strains capable of causing the disease (Veh et al., 2015). In addition, the level of expression or the subset of Staph. aureus genes expressed during infection is profoundly different than that seen in vitro (Allard et al., 2006, 2013) or between strains (Capra et al., 2017). However, despite these discrepancies, the genomic constitution and phenotypic traits of Staph. aureus mastitis isolates are the result of a long-term evolutionary adaptation to the bovine host (Bergonier et al., 2014). Notwithstanding, such a host adaptation is very apparent when the different lineages of mastitis-causing strains are compared with human strains (Fitzgerald, 2012; Rainard et al., 2018). Outbreaks of 
non-bovine-associated strains have been reported, some of which were caused by strains carrying antibiotic resistance cassettes (Hata, 2016).

Numerous molecular typing methods have been developed for epidemiological studies, including multilocus sequence typing, pulsed-field gel electrophoresis, variable numbers of tandem repeat loci typing (Sabat et al., 2003; Pourcel et al., 2009), and analysis of the polymorphic X region of the protein A gene (spa). These typing methods can then be used to associate some strain types with certain genetic and phenotypic characteristics of Staph. aureus such as biofilm production, antimicrobial susceptibility, presence of specific virulence genes, and the ability to invade and persist within host cells (Veh et al., 2015; Ster et al., 2017). For instance, $S$. aureus mastitis strains of different sequence types were shown to produce a diversity of superantigen arrays, each having the ability to induce $\mathrm{V} \beta$-specific proliferation of bovine $\mathrm{T}$ cells and with some arrays able to stimulate the entire $\mathrm{T}$ cell repertoire (Wilson et al., 2018). At the diagnostic level, an interesting approach lies in the potential use of molecular typing to predict the severity and persistence of IMI following identification of the strain causing infection. However, lineage may not always the best marker to predict the severity of infection. Indeed, there could be important differences in the expression levels of toxins and proteases among genetically related Staph. aureus strains (Le Maréchal et al., 2011) or between in vitro and in vivo gene expression profiles (Allard et al., 2006). Furthermore, within a single strain, gene expression can change as the infection progresses over time (Jenkins et al., 2015).

\section{Staph. aureus Small-Colony Variants}

Over the last decades, a phenotypic variant of Staph. aureus has been isolated and characterized in many cases of chronic disease: the small-colony variant (SCV). As the name suggests, the main phenotypic feature associated with these subpopulations of isolates is slower growth, leading to the formation of small, nonpigmented and nonhemolytic colonies about one-tenth of the normal size of Staph. aureus colonies on solid culture medium (Proctor et al., 2006). These characteristics can be explained by the particular metabolic profile of SCV (Kriegeskorte et al., 2014). The majority of clinical Staph. aureus SCV are thought to derive from specific point mutations that lead to deficiencies in the electron transport chain, altering the oxidative phosphorylation process (Kahl et al., 2016).

In addition to the tolerance and resistance of SCV to certain antibiotics, which can be explained by their slow growth and altered metabolism, a specific transcriptional signature allows expression of a set of virulence genes associated with persistence in the host. Small-colony variants have increased capacity for biofilm production (Mitchell et al., 2010; Singh et al., 2010) and an improved ability to invade and survive within host cells compared with prototypic Staph. aureus (Kalinka et al., 2014; Löffler et al., 2014). As mentioned above, the expression of virulence factors associated with dissemination and tissue invasion in prototypic Staph. aureus is, for the most part, under the control of the quorum-sensing mechanism (the Agr system). On the other hand, because of the slow growth of SCV, SigB preferentially influences the expression of adhesins and biofilm formation in SCV (Mitchell et al., 2013). It is generally accepted that SCV have increased ability to adhere and invade host cells due to high expression of FnBP and, once internalized in host cells, the intracellular persistence of SCV is due, at least in part, to decreased expression of $\alpha$-hemolysin compared with prototypic Staph. aureus (Tuchscherr et al., 2011). Interestingly, although the modified expression of FnBP and $\alpha$-hemolysin is in fact attributable to the opposing influence of SigB and Agr, Agr could not promote the expression of $\alpha$-hemolysin in absence of a functional transport chain, as is generally the case for SCV (Pader et al., 2014). Upon selective pressure (e.g., antibiotic treatment, the host immune response, or the intracellular milieu), SCV can be generated and, after release of the selective pressure, the prototypic phenotype can occur from the reversed mutation and be selected by its growth performance and dissemination abilities over the SCV phenotype. It was proposed that such a phenotypic switching is intrinsic to Staph. aureus pathogenesis and allows establishment of chronic infections (Tuchscherr et al., 2011).

Small-colony variants are indeed frequently found in chronic infections (Kahl et al., 2016). In recent years, SCV have often been isolated from clinical samples of difficult-to-treat infections such as respiratory tract infections in cystic fibrosis patients, deep post-surgery infections, chronic osteomyelitis, and foreign body infections such as those associated with prosthetic joint and implants as well as from chronic cases of bovine mastitis (Atalla et al., 2008; Alkasir et al., 2013; Yagci et al., 2013; Kalinka et al., 2014; Yang et al., 2018). Certain factors present in these environments may favor the emergence of the persistent phenotype, including antibiotic treatments. Several studies have already reported resistance of SCV to many antibiotics (Vaudaux et al., 2011; Gläser et al., 2014), including aminoglycosides and some cationic peptides that depend on the respiratory chain and membrane potential $(\Delta \Psi)$ for their mode 
of action (Proctor et al., 2006). Also, the intracellular environment itself may contribute to the emergence of SCV (Tan et al., 2014). Unfortunately, it appears that the prevalence of SCV in the clinical context is still greatly undervalued, in part due to the difficulty in detecting the atypical Staph. aureus phenotype in clinical samples (Atalla et al., 2010; Yagci et al., 2013). Recurrent antibiotic treatments and internalization of Staph. aureus in epithelial mammary gland cells may indeed represent conditions proper to the generation of the SCV phenotype (Atalla et al., 2010) and potentially explain some of the relatively low cure rates observed for Staph. aureus IMI, which often require extended antibiotic therapies (Roy and Keefe, 2012). Furthermore, the host innate immune response for SCV is reduced compared with that observed for the normal phenotype (Ou et al., 2016), and SCV resist the oxidative burst of purified neutrophils and in blood (Painter et al., 2017). Together with the ability of SCV to invade and survive in host cells and their propensity to dynamically revert to an invasive phenotype under more permissive conditions, Staph. aureus survival strategies may thus contribute to the establishment of chronic infections by escaping the action of both antimicrobial therapies and host immunity.

\section{VACCINE STRATEGIES}

\section{Targeting Bacterial Antigens Expressed During Infection}

As mentioned above, Staph. aureus strains responsible for bovine mastitis are diverse and can be phenotypically very different. Moreover, Staph. aureus gene expression will vary considerably with the phase of infection and in response to the extracellular and intracellular environments. Consequently, a common protective antigen that would be useful against multiple Staph. aureus strains has not yet been discovered; very few subunit vaccine compositions have demonstrated substantial benefit to date (Middleton et al., 2009). Also, the selected antigen targets are not necessarily expressed in vivo by all strains or in the mammary gland environment. The in vivo environment can indeed modulate gene expression in Staph. aureus (Lowe et al., 1998; Allard et al., 2006). The in vivo expression of some specific known virulence factors was studied previously but it represented a limited selection of targets for vaccine development (Tollersrud et al., 2006). Other studies looked more broadly at Staph. aureus proteins and genes that could be expressed in vivo using in vitro culture conditions that could represent the mammary gland or milk environment (Lammers et al., 2000; Taverna et al., 2007).
Because these alternative media and growth conditions do not completely replicate the mammary gland environment or mastitic milk, our research team proceeded to experimentally infect cows to collect milk and bacteria during mastitis, and by a transcriptomic approach, examined genes that were strongly expressed by Staph. aureus during infection (Allard et al., 2013). Furthermore, in those experiments, several cows and multiple Staph. aureus strains of a variety of spa types were used to include host effects as well as strain genotypic and phenotypic diversity. Intramammary infections were followed for $18 \mathrm{~d}$, which allowed us to identify a selection of bacterial genes that were strongly expressed by several Staph. aureus strains in a sustained manner during the infection period and in several cows. This approach led to identification of genes and protein candidates for vaccine or drug development.

Among others, gene vraG (coding for a putative ABC transporter permease) was shown to be strongly induced by Staph. aureus during mastitis (Allard et al., 2013). Because inactivation of that gene by mutagenesis led to a mutant that was significantly attenuated during experimental bovine IMI, the importance of VraG in virulence could be demonstrated (Allard et al., 2013). In fact, VraG seems to be required for cationic antimicrobial peptide sensing and resistance in Staph. aureus (Falord et al., 2012). Antimicrobial peptides are an important line of defense for the host against microbial pathogens (Hancock, 2001).

Examining Staph. aureus genes that are expressed during bovine mastitis also helped us identify novel drug targets, and we reported that the expression of the essential gene guaA, which codes for the enzyme guanosine monophosphate (GMP) synthase and is regulated by a guanine riboswitch (Mulhbacher et al., 2010), could be suppressed by a drug-like small-molecule riboswitch ligand acting as an "antibioswitch." Such a novel class of antibiotic was shown to have some degree of success for the treatment of bovine mastitis (Ster et al., 2013).

In a recent study, an immunoproteomics approach was used to identify antigenic proteins from the surface of Staph. aureus to find new potential vaccine candidates (Misra et al., 2018). More specifically, proteins expressed by bacteria grown under iron-restricted conditions to mimic the mammalian host environment were extracted, separated, and blotted followed by specific detection with antibodies from mastitic milk. Thirtyeight Staph. aureus proteins were commonly detected by antibodies present in sera of several cows, of which 8 were predicted to be surface-associated and previously determined to be involved in Staph. aureus virulence. Of those, 2 surface proteins, the iron-regulated surface determinant protein $\mathrm{C}$ (IsdC) and ESAT-6 secretion 
system extracellular protein EsxA, were cloned and purified in E. coli and then confirmed to be immunoreactive with antibodies from different cows with Staph. aureus mastitis. Misra et al. (2018) recognized, however, that this immunoproteomics approach could not distinguish between proteins that are reactive but not protective, although it could represent another effective way to identify new vaccine candidates.

\section{Inactivated and Live Attenuated Vaccines}

An inactivated Staph. aureus vaccine (StartVac or TopVac; Laboratorios Hipra S.A., Amer, Spain) is commercially available for bovine mastitis. This multivalent vaccine has a Staph. aureus component - a bacterin representing strains that express slime-associated antigens part of the biofilm extracellular matrix (Prenafeta et al., 2010). Although the use of a whole bacterin provides a selection of antigens that are suitable for raising an immune response, the success of such an approach is highly dependent on the diversity and type of the Staph. aureus strains present in herds. As such, discrepancies in the observed benefit of this vaccine reported in various studies may be attributed to the diversity of Staph. aureus strains, which varies geographically, as well as in the degree of slime and biofilm production that may depend on the bacterial growth phase or the environment (Schukken et al., 2014; Bradley et al., 2015; Landin et al., 2015).

Live-attenuated vaccines are still among the most widely used vaccination technologies today. Attenuated vaccines consist of bacterial or viral strains that are deliberately weakened until they are considered harmless or sufficiently less virulent, allowing them to only colonize the target host transiently. Traditionally, live attenuated vaccines have been developed by passage of pathogens under in vitro conditions until they lose their virulence. This empirical approach has been used in the case of the Mycobacterium bovis strain BCG for vaccination of humans against tuberculosis. It is now widely recommended that an attenuation strategy be more specific and precise; for example, by using targeted mutations affecting both virulence factors and metabolism (Galen and Curtiss, 2014). Complete gene deletions, compared with mutagenesis of single sites, are considered safer because of the impossibility of reversion, although the acquisition of complete functional virulence genes is theoretically possible via horizontal transfer from environmental bacteria (Frey, 2007).

Live vaccines have several advantages over formulations that use inactivated strains or subunit vaccines that contain purified antigens; for example, (1) they mimic a natural infection and therefore can cause im- mune responses that are specific, localized, effective, and long lasting (Detmer and Glenting, 2006), and (2) they can prevent the first stages of infection by the pathogen, not just the symptoms of the disease (Frey, 2007). Live-attenuated vaccines also have the significant advantage of offering a broad range of antigenic targets and act intrinsically as what could be called natural adjuvants, by enhancing antigenic presentation through the stimulation of pattern recognition receptors ( Griffiths and Khader, 2014). In addition, they can be used as antigenic live vectors for in situ expression of heterologous or modified antigenic proteins via plasmid or chromosomal expression systems. Many intracellular pathogens, such as Listeria monocytogenes, have not only been used for their live-attenuated vaccine qualities, but also for their ability to escape the phagolysosome after phagocytosis and to reach the cytoplasm of the infected host cells, where antigen presentation through the major histocompatibility complex (MHC)-I for stimulation of cellular immunity is possible (Bruhn et al., 2007). Live-attenuated Salmonella typhimurium (i.e., Salmonella enterica ssp. enterica serovar Typhimurium) strains were also used to deliver recombinant foreign antigens with interesting results (Zheng et al., 2012), notably with the combination of SPI-1 Type 3 secretion system and Staph. aureus recombinant EsxA and B proteins. Indeed, this approach allows the recognition of the antigens produced by the bacterium by both MHC-I and MHC-II, because the antigens are delivered by Salmonella directly into the cytoplasm.

We recently used a combination of the aforementioned elements to create a novel attenuated mutant of Staph. aureus that could be used as a vaccine for bovine mastitis (Côté-Gravel et al., 2016). The strategy took into consideration a critical phenotype part of Staph. aureus pathogenesis - SCV formation, which provides the possibility of delivering antigens in the host cell cytoplasmic compartment. Moreover, to avoid reversion to the invasive prototypic phenotype, we used a deletion of the hemB gene to create a stable and irreversible SCV phenotype. In addition, as seen in the Staph. aureus Small-Colony Variants subsection, although SCV are naturally attenuated in their virulence compared with prototypic strains, their ability to be internalized and to persist within host cells is an important aspect of Staph. aureus pathogenesis. Hence, a vraG mutation was introduced in the hemB SCV background to create an SCV double mutant incapable of sustaining an infection in a mouse mastitis model (Côté-Gravel et al., 2016). Indeed, as described in the Targeting Bacterial Antigens Expressed During Infection subsection, $v r a G$ is one of the Staph. aureus genes that is strongly 
expressed during bovine mastitis and that was shown to be an important determinant of virulence in experimental bovine IMI (Allard et al., 2013). As a result, immunization of mice with such a live-attenuated double mutant raised a strong humoral response and antibodies that could also recognize strains from a variety of common mastitis associated spa types (Côté-Gravel et al., 2016). Additionally, significantly higher $\operatorname{IgG}_{2}: \operatorname{IgG}_{1}$ titer ratios, which are indicative of a balanced T-helper (Th)1- and Th2-oriented immune response, were detected in sera obtained from mice immunized with the live-attenuated double mutant compared with those of mice vaccinated with the purified IsdH protein.

\section{Immune Responses for Protection}

The ability to stimulate a balanced humoral and cellular immune response may be key to achieving protection against Staph. aureus. Immunological response to Staph. aureus in the mammary gland of ruminants has been reviewed elsewhere (Hughes and Watson, 2018; Rainard et al., 2018). To summarize, the mammary gland of ruminants exploits various types of mechanisms to block the penetration and dissemination of microorganisms. As seen in the Pathogenesis of Staph. aureus IMI section, the gland is first protected against the entry of pathogens by structural defenses, among which the physical barrier constituted by the teat canal is undoubtedly one of the most important. The smooth muscle sphincters surrounding the teat canal also prevent leakage of milk by maintaining a tight closure and by producing a keratin layer by the epithelium lining of the duct between milking periods (Aitken et al., 2011). During lactation, the pressure build-up in the udder and the periodic opening of this canal during milking facilitate access of bacteria to the rest of the gland, where they are more likely to proliferate and cause an infection. Once bacteria have entered the cistern, the host innate immunity and adaptive immunity take over and operate in a coordinated manner. This specific response takes action with the presentation of pathogen antigens by specialized antigen-presenting cells (e.g., dendritic cells) and their recognition by naïve circulating $\mathrm{B}$ and $\mathrm{T}$ lymphocytes. The antigen-specific activated $\mathrm{T}$ and $\mathrm{B}$ cells then undergo clonal expansion of effector and memory cells through the triggering of specific proliferation cytokines that will influence the type of resulting lymphocyte subsets depending on the type of pathogen, MHC presentation pathway, and influence of cellular regulators during activation (Guzman et al., 2014). These subsets will then correspondingly influence the type of adaptive response that will occur in the gland by regulating specific and nonspecific im- mune responses (Ezzat Alnakip et al., 2014). During the early stages of infection, the principal actions of innate immunity are unfolded through the pattern recognition receptor pathways and the subsequent outburst of pro-inflammatory cytokines, which include tumor necrosis factor $\alpha$ (TNF- $\alpha$ ) and IL-1 $\beta$, among others (Oviedo-Boyso et al., 2007). These specific cytokines promote the rapid recruitment of specialized cellular actors such as the neutrophils and macrophages, which can directly ingest microorganisms by phagocytosis and produce soluble defense components; namely, myeloperoxidase and its generation of reactive oxygen species, antimicrobial peptides, immune-modulating proteins, oligosaccharides, lysozyme, lactoferrin, and complement system components (Aitken et al., 2011; Ezzat Alnakip et al., 2014). Neutrophils are the most important phagocytic cells and are the dominant innate cellular defense against mastitis-causing pathogens in the udder (Rainard and Riollet, 2006), and this seems specifically true against Staph. aureus (Spaan et al., 2013). When the innate immunity is not sufficient to clear pathogens, the host adaptive system is activated, and the dominance of neutrophils is shifted to an increasing number of lymphocytes and monocytes (Oviedo-Boyso et al., 2007).

The type of pathogen greatly influences the host response to infection (Petzl et al., 2018). Most coliform species that cause mastitis elicit a marked acute inflammatory response compared with Staph. aureus because of the presence of lipopolysaccharide (Ezzat Alnakip et al., 2014). Indeed, the outcome of a coliform-caused clinical mastitis is completely different from one originating from a persistent subclinical Staph. aureus IMI (Jensen et al., 2013). In a recent transcriptional analysis of the mammary gland's early response to an experimentally induced bovine mastitis, it was found that Staph. aureus IMI, in contrast to those caused by E. coli, did not modulate the expression level of any of the nuclear factor (NF)- $\kappa B$ factors or their inhibitory I $\kappa$ B regulators (Günther et al., 2017), as previously reported using Staph. aureus-stimulated mammary epithelial cells in vitro (Günther et al., 2011). Moreover, activation of the Wnt/ $\beta$-catenin cascade that provokes suppression of NF- $\kappa \mathrm{B}$ signaling and rearrangement of the actin cytoskeleton facilitate invasion of bacteria into host cells. Hence, Günther et al. (2017) proposed that Staph. aureus triggers some immune suppression during mastitis. This immunomodulation or dampening of immunity, together with the ability of Staph. aureus to invade and persist in host cells, can allow Staph. aureus to maintain an effective infection for an extended period. Similarly, another recent study revealed significant transcriptomic differences in microRNA expression of 
bovine mammary glands infected with Staph. aureus and E. coli (Luoreng et al., 2018).

It is suggested that a vaccine that allows the development of a more balanced immunity, with a strong component of cell-mediated immunity, is necessary for protection against pathogens responsible for chronic infections (Kovacs-Nolan et al., 2009). More specifically, it appears that cell-mediated immunity based on Th1 and Th17 type responses may be necessary for protection (Lin et al., 2009; Spellberg and Daum, 2012; Fowler and Proctor, 2014). Thus, new ways to specifically stimulate the Th-1 and Th-17 pathways for the development of effective Staph. aureus vaccines are presently being explored (Lacey et al., 2017). It has been shown that antigen-specific Th- 1 and Th-17 inflammatory responses are possible following intramammary immunization of cows with a sensitizing protein (Rainard et al., 2013). Another important goal would be to effectively increase the concentration of local or intramammary cell-mediated actors and antibodies in milk. For this purpose, different routes of immunization for vaccine administration, such as intramammary or intranasal inoculations, may provide ways to modulate and accentuate a local response (Boerhout et al., 2015).

\section{ADJUVANTS AND IMMUNOMODULATION STRATEGIES}

The development of a subunit vaccine that uses recombinant proteins was stimulated by several advantages, including the cost-effective preparation of specific and relevant antigens, thus eliminating host immune responses toward less important targets or suppressive antigens. Such an approach has, however, prompted a quest for adjuvants that could enhance both humoral and cellular immune responses. The diversity of adjuvants used in different vaccine formulations has been extensively reviewed by several authors (Nicholls et al., 2010; Savelkoul et al., 2015; Burakova et al., 2018). In addition, it has been shown recently that not only the type of adjuvant used for immunization but also the location of a subcutaneous injection can influence the isotypes and titers of antibodies produced in cattle; higher titers were effectively obtained from a prime immunization near the udder with an alum-saponin-oil adjuvant compared with immunization in the neck (Boerhout et al., 2018). The authors of that study hypothesized that with an immunization near the teat, antigens could be taken up by the supramammary lymph nodes, which are more likely to have previously been in natural contact with Staph. aureus compared with the prescapular lymph nodes in the neck, and therefore only a single dose of immunization was needed to induce similar effects.
Typical adjuvants include aluminum salts and oiland-water emulsions of various types that can modulate the release of antigens. Others include pathogen-associated molecular patterns (PAMP) and toll-like receptor agonists that stimulate the innate immune response, as well as some polymers that can either carry antigens or act as immunostimulants on their own. Chitosan is one such a polymer that shows interesting properties. In a recent study, a chitosan-based formulation injected into the teat canal was shown to promote immune cell migration and accelerate mammary gland involution at dry-off, and it was proposed as an alternative to dry cow therapy (Lanctôt et al., 2017). Chitosan is composed of D-glucosamine and $\mathrm{N}$-acetyl-D-glucosamine units linked by $\beta$-1,4-glycosidic linkages, and its biological activity depends on its molecular weight and the degree of deacetylation. Interestingly, our group demonstrated that a $2.6-\mathrm{kDa}$ chitosan (98\% $N$-deacetylated) possessed antibacterial activity against Staph. aureus and could help reduce antibiotic use in dairy farms (Asli et al., 2017).

Approaches attempting direct immunomodulation of the udder by cytokines and other response modulators could represent alternatives to vaccination; such studies were reviewed by Petzl et al. (2018). A commercially available example of such an immunomodulator is the granulocyte colony stimulating factor pegbovigrastim (Imrestor; Elanco Animal Health, Greenfield, IN) that is proposed to help restoring neutrophil function during the periparturient period; that is, when cows are most susceptible to mastitis (Canning et al., 2017).

Finally, based on our own experience with live-attenuated strains as vaccines, which induce strong and balanced $\mathrm{B}$ and $\mathrm{T}$ cell immune responses compared with purified protein antigens, the concept of using microbe-mimicking or microbe-derived membrane vesicles for antigen delivery represents an attractive new perspective. Indeed, naturally occurring microbial membrane vesicles are increasingly recognized for their immunomodulatory effects on host immune responses (Kaparakis-Liaskos and Ferrero, 2015; Ahmadi Badi et al., 2017; Bitto and Kaparakis-Liaskos, 2017), and engineered-membrane vesicles can be used as vaccine delivery systems (Bai et al., 2011).

\section{CONCLUSIONS}

Bovine mastitis is the most common reason for antibiotic use in dairy farms. In the One Health concept, which acknowledges the interconnection between human and animal health and the environment, vaccines play a key role in disease prevention and are part of the effort to reduce the use of antibiotics. The challenges in the development of a vaccine for prevention 
of Staph. aureus mastitis are several. In this review, we underscored the complex pathogenesis associated with this microorganism, which presents invasive and persistent phenotypes. Added to this is a large diversity of mastitis-causing strains, which reduces the probability of finding a universal vaccine. However, selection of relevant antigenic targets for vaccine development has been greatly aided by omics technologies but the need to stimulate both humoral and cellular immunity responses in order to control this bacterium requires innovative adjuvant or immunomodulatory strategies. Overall, a vaccine that offers full protection against Staph. aureus IMI is perhaps idealistic at this time but current and future approaches that could reduce disease prevalence should be viewed as important contributions in the field because of their direct effects on antibiotic use in dairy farms.

\section{ACKNOWLEDGMENTS}

Research described as from the Malouin laboratory was supported by a contribution from the Dairy Research Cluster initiative [Dairy Farmers of Canada (Ottawa, ON, Canada), Agriculture and Agri-Food Canada (Ottawa, ON, Canada), and the Canadian Dairy Commission (Ottawa, ON, Canada)] through the Canadian Bovine Mastitis and Milk Quality Research Network (St-Hyacinthe, QC, Canada). This research was also funded by the Regroupement de recherche pour un lait de qualité optimale (Op+lait; St-Hyacinthe, QC, Canada) supported by the Fonds de Recherche du Québec-Nature et Technologies (FRQNT). This research was also funded by the Natural Sciences and Engineering Research Council of Canada (NSERC grant No. 2015-05916 to FM). JCG obtained studentships from Op+lait and from the NSERC CREATE program in milk quality.

\section{REFERENCES}

Aghamohammadi, M., D. Haine, D. F. Kelton, H. W. Barkema, H. Hogeveen, G. P. Keefe, and S. Dufour. 2018. Herd-level mastitisassociated costs on Canadian dairy farms. Front. Vet. Sci. 5:100. https://doi.org/10.3389/fvets.2018.00100.

Ahmadi Badi, S., A. Moshiri, A. Fateh, F. R. Jamnani, M. Sarshar, F. Vaziri, and S. D. Siadat. 2017. Microbiota-derived extracellular vesicles as new systemic regulators. Front. Microbiol. 8:1610. https://doi.org/10.3389/fmicb.2017.01610.

Aitken, S. L., C. M. Corl, and L. M. Sordillo. 2011. Immunopathology of mastitis: Insights into disease recognition and resolution. J. Mammary Gland Biol. Neoplasia 16:291-304. https://doi.org/10 .1007/s10911-011-9230-4.

Alkasir, R., X. Liu, M. Zahra, M. Ferreri, J. Su, and B. Han. 2013. Characteristics of Staphylococcus aureus small colony variant and its parent strain isolated from chronic mastitis at a dairy farm in Beijing, China. Microb. Drug Resist. 19:138-145. https://doi.org/ 10.1089/mdr.2012.0086.
Allard, M., H. Moisan, É. Brouillette, A. L. Gervais, M. Jacques, P. Lacasse, M. S. Diarra, and F. Malouin. 2006. Transcriptional modulation of some Staphylococcus aureus iron-regulated genes during growth in vitro and in a tissue cage model in vivo. Microbes Infect. 8:1679-1690. https://doi.org/10.1016/j.micinf.2006.01.022.

Allard, M., C. Ster, C. L. Jacob, D. Scholl, M. S. Diarra, P. Lacasse, and F. Malouin. 2013. The expression of a putative exotoxin and an $\mathrm{ABC}$ transporter during bovine intramammary infection contributes to the virulence of Staphylococcus aureus. Vet. Microbiol. 162:761-770. https://doi.org/10.1016/j.vetmic.2012.09.029.

Asli, A., E. Brouillette, C. Ster, M. G. Ghinet, R. Brzezinski, P. Lacasse, M. Jacques, and F. Malouin. 2017. Antibiofilm and antibacterial effects of specific chitosan molecules on Staphylococcus aureus isolates associated with bovine mastitis. PLoS One 12:e0176988. https://doi.org/10.1371/journal.pone.0176988.

Atalla, H., C. Gyles, C. L. Jacob, H. Moisan, F. Malouin, and B. Mallard. 2008. Characterization of a Staphylococcus aureus small colony variant (SCV) associated with persistent bovine mastitis. Foodborne Pathog. Dis. 5:785-799. https://doi.org/10.1089/fpd .2008 .0110

Atalla, H., C. Gyles, and B. Mallard. 2010. Persistence of a Staphylococcus aureus small colony variants $(S$. aureus $\mathrm{SCV})$ within bovine mammary epithelial cells. Vet. Microbiol. 143:319-328. https://doi .org/10.1016/j.vetmic.2009.11.030.

Bai, X., J. Findlow, and R. Borrow. 2011. Recombinant protein meningococcal serogroup B vaccine combined with outer membrane vesicles. Expert Opin. Biol. Ther. 11:969-985. https://doi.org/10 $.1517 / 14712598.2011 .585965$.

Bar, D., L. W. Tauer, G. Bennett, R. N. González, J. A. Hertl, Y. H Schukken, H. F. Schulte, F. L. Welcome, and Y. T. Gröhn. 2008 The cost of generic clinical mastitis in dairy cows as estimated by using dynamic programming. J. Dairy Sci. 91:2205-2214. https:// doi.org/10.3168/jds.2007-0573.

Barkema, H. W., Y. H. Schukken, and R. N. Zadoks. 2006. Invited review: The role of cow, pathogen, and treatment regimen in the therapeutic success of bovine Staphylococcus aureus mastitis. J. Dairy Sci. 89:1877-1895. https://doi.org/10.3168/jds.S0022 -0302(06)72256-1.

Bergonier, D., D. Sobral, A. T. Feßler, E. Jacquet, F. B. Gilbert, S. Schwarz, M. Treilles, P. Bouloc, C. Pourcel, and G. Vergnaud. 2014. Staphylococcus aureus from 152 cases of bovine, ovine and caprine mastitis investigated by Multiple-locus variable number of tandem repeat analysis (MLVA). Vet. Res. 45:97. https://doi.org/ 10.1186/s13567-014-0097-4.

Bitto, N. J., and M. Kaparakis-Liaskos. 2017. The therapeutic benefit of bacterial membrane vesicles. Int. J. Mol. Sci. 18:1287. https:// doi.org/10.3390/ijms18061287.

Boerhout, E., M. Vrieling, L. Benedictus, I. Daemen, L. Ravesloot, V. Rutten, P. Nuijten, J. van Strijp, A. Koets, and S. Eisenberg. 2015. Immunization routes in cattle impact the levels and neutralizing capacity of antibodies induced against $S$. aureus immune evasion proteins. Vet. Res. 46:115. https://doi.org/10.1186/s13567 $-015-0243-7$.

Boerhout, E. M., A. P. Koets, T. G. T. Mols-Vorstermans, P. J. M. Nuijten, M. J. H. Hoeijmakers, V. P. M. G. Rutten, and J. J. E. Bijlsma. 2018. The antibody response in the bovine mammary gland is influenced by the adjuvant and the site of subcutaneous vaccination. Vet. Res. 49:25. https://doi.org/10.1186/s13567-018 -0521-2.

Boisset, S., T. Geissmann, E. Huntzinger, P. Fechter, N. Bendridi, M. Possedko, C. Chevalier, A. C. Helfer, Y. Benito, A. Jacquier, C. Gaspin, F. Vandenesch, and P. Romby. 2007. Staphylococcus aureus RNAIII coordinately represses the synthesis of virulence factors and the transcription regulator Rot by an antisense mechanism. Genes Dev. 21:1353-1366. https://doi.org/10.1101/gad.423507.

Bradley, A. J., J. E. Breen, B. Payne, V. White, and M. J. Green. 2015. An investigation of the efficacy of a polyvalent mastitis vaccine using different vaccination regimens under field conditions in the United Kingdom. J. Dairy Sci. 98:1706-1720. https://doi.org/ $10.3168 /$ jds.2014-8332. 
Brouillette, E., B. G. Talbot, and F. Malouin. 2003. The fibronectinbinding proteins of Staphylococcus aureus may promote mammary gland colonization in a lactating mouse model of mastitis. Infect. Immun. 71:2292-2295. https://doi.org/10.1128/IAI.71.4.2292 $-2295.2003$.

Bruhn, K. W., N. Craft, and J. Miller. 2007. Listeria as a vaccine vector. Microbes Infect. 9:1226-1235. https://doi.org/10.1016/j .micinf.2007.05.010.

Burakova, Y., R. Madera, S. McVey, J. R. Schlup, and J. Shi. 2018. Adjuvants for animal vaccines. Viral Immunol. 31:11-22. https:// doi.org/10.1089/vim.2017.0049.

Canning, P., R. Hassfurther, T. TerHune, K. Rogers, S. Abbott, and D. Kolb. 2017. Efficacy and clinical safety of pegbovigrastim for preventing naturally occurring clinical mastitis in periparturient primiparous and multiparous cows on US commercial dairies. J. Dairy Sci. 100:6504-6515. https://doi.org/10.3168/jds.2017-12583.

Capra, E., P. Cremonesi, A. Pietrelli, S. Puccio, M. Luini, A. Stella, and B. Castiglioni. 2017. Genomic and transcriptomic comparison between Staphylococcus aureus strains associated with high and low within herd prevalence of intra-mammary infection. BMC Microbiol. 17:21. https://doi.org/10.1186/s12866-017-0931-8.

Condas, L. A. Z., J. De Buck, D. B. Nobrega, D. A. Carson, S. Naushad, S. De Vliegher, R. N. Zadoks, J. R. Middleton, S. Dufour, J. P. Kastelic, and H. W. Barkema. 2017. Prevalence of non-aureus staphylococci species causing intramammary infections in Canadian dairy herds. J. Dairy Sci. 100:5592-5612. https://doi.org/10 .3168/jds.2016-12478.

Contreras, G. A., and J. M. Rodriguez. 2011. Mastitis: Comparative etiology and epidemiology. J. Mammary Gland Biol. Neoplasia 16:339-356. https://doi.org/10.1007/s10911-011-9234-0.

Côté-Gravel, J., E. Brouillette, N. Obradović, C. Ster, B. G. Talbot, and F. Malouin. 2016. Characterization of a vraG mutant in a genetically stable Staphylococcus aureus small-colony variant and preliminary assessment for use as a live-attenuated vaccine against intramammary infections. PLoS One 11:e0166621. https://doi .org/10.1371/journal.pone.0166621.

Detmer, A., and J. Glenting. 2006. Live bacterial vaccines-A review and identification of potential hazards. Microb. Cell Fact. 5:23. https://doi.org/10.1186/1475-2859-5-23.

Dinsmore, R. P. 2002. Biosecurity for mammary diseases in dairy cattle. Vet. Clin. North Am. Food Anim. Pract. 18:115-131.

Ezzat Alnakip, M., M. Quintela-Baluja, K. Böhme, I. Fernández-No, S. Caamaño-Antelo, P. Calo-Mata, and J. Barros-Velázquez. 2014. The immunology of mammary gland of dairy ruminants between healthy and inflammatory conditions. J. Vet. Med. 2014:659801. https://doi.org/10.1155/2014/659801.

Falord, M., G. Karimova, A. Hiron, and T. Msadek. 2012. GraXSR proteins interact with the VraFG ABC transporter to form a five-component system required for cationic antimicrobial peptide sensing and resistance in Staphylococcus aureus. Antimicrob. Agents Chemother. 56:1047-1058. https://doi.org/10.1128/AAC .05054-11.

Fitzgerald, J. R. 2012. Livestock-associated Staphylococcus aureus: Origin, evolution and public health threat. Trends Microbiol. 20:192-198. https://doi.org/10.1016/j.tim.2012.01.006.

Fowler, V. G., and R. Proctor. 2014. Where does a Staphylococcus aureus vaccine stand? Clin. Microbiol. Infect. 20(Suppl. 5):66-75. https://doi.org/10.1111/1469-0691.12570.

Frey, J. 2007. Biological safety concepts of genetically modified live bacterial vaccines. Vaccine 25:5598-5605. https://doi.org/10 $.1016 /$ j.vaccine.2006.11.058.

Galen, J. E., and R. Curtiss. 2014. The delicate balance in genetically engineering live vaccines. Vaccine 32:4376-4385. https://doi.org/ 10.1016/j.vaccine.2013.12.026.

García-Álvarez, L., M. T. G. Holden, H. Lindsay, C. R. Webb, D. F. J. Brown, M. D. Curran, E. Walpole, K. Brooks, D. J. Pickard, C. Teale, J. Parkhill, S. D. Bentley, G. F. Edwards, E. K. Girvan, A. M. Kearns, B. Pichon, R. L. R. Hill, A. R. Larsen, R. L. Skov, S. J. Peacock, D. J. Maskell, and M. A. Holmes. 2011. Meticillinresistant Staphylococcus aureus with a novel mecA homologue in human and bovine populations in the UK and Denmark: A descriptive study. Lancet Infect. Dis. 11:595-603. https://doi.org/10 .1016/S1473-3099(11)70126-8.

Gläser, R., K. Becker, C. von Eiff, U. Meyer-Hoffert, and J. Harder. 2014. Decreased susceptibility of Staphylococcus aureus smallcolony variants toward human antimicrobial peptides. J. Invest. Dermatol. 134:2347-2350. https://doi.org/10.1038/jid.2014.176.

Griffiths, K. L., and S. A. Khader. 2014. Novel vaccine approaches for protection against intracellular pathogens. Curr. Opin. Immunol. 28:58-63. https://doi.org/10.1016/j.coi.2014.02.003.

Günther, J., K. Esch, N. Poschadel, W. Petzl, H. Zerbe, S. Mitterhuemer, H. Blum, and H. M. Seyfert. 2011. Comparative kinetics of Escherichia coli- and Staphylococcus aureus-specific activation of key immune pathways in mammary epithelial cells demonstrates that $S$. aureus elicits a delayed response dominated by interleukin-6 (IL-6) but not by IL-1A or tumor. Infect. Immun. 79:695707. https://doi.org/10.1128/IAI.01071-10.

Günther, J., W. Petzl, I. Bauer, S. Ponsuksili, H. Zerbe, H. J. Schuberth, R. M. Brunner, and H. M. Seyfert. 2017. Differentiating Staphylococcus aureus from Escherichia coli mastitis: S. aureus triggers unbalanced immune-dampening and host cell invasion immediately after udder infection. Sci. Rep. 7:4811. https://doi.org/ 10.1038/s41598-017-05107-4.

Guzman, E., J. Hope, G. Taylor, A. L. Smith, C. Cubillos-Zapata, and B. Charleston. 2014. Bovine $\gamma \delta$ T cells are a major regulatory T cell subset. J. Immunol. 193:208-222. https://doi.org/10.4049/ jimmunol.1303398.

Halasa, T., K. Huijps, O. Østerås, and H. Hogeveen. 2007. Economic effects of bovine mastitis and mastitis management: A review. Vet. Q. 29:18-31. https://doi.org/10.1080/01652176.2007.9695224.

Hancock, R. E. 2001. Cationic peptides: Effectors in innate immunity and novel antimicrobials. Lancet Infect. Dis. 1:156-164. https:// doi.org/10.1016/S1473-3099(01)00092-5.

Hata, E. 2016. Bovine mastitis outbreak in Japan caused by methicillin-resistant Staphylococcus aureus New York/Japan clone. J. Vet. Diagn. Invest. 28:291-298. https://doi.org/10.1177/ 1040638716643126.

Hathroubi, S., M. A. Mekni, P. Domenico, D. Nguyen, and M. Jacques. 2017. Biofilms: Microbial Shelters Against Antibiotics. Microb. Drug Resist. 23:147-156. https://doi.org/10.1089/mdr.2016.0087.

Hoekstra, J., V. Rutten, L. Sommeling, T. van Werven, M. Spaninks, B. Duim, L. Benedictus, and G. Koop. 2018. High production of LukMF' in Staphylococcus aureus field strains is associated with clinical bovine mastitis. Toxins (Basel) 10:200. https://doi.org/10 $.3390 /$ toxins 10050200 .

Hogan, J., and K. L. Smith. 2003. Coliform mastitis. Vet. Res. 34:507519. https://doi.org/10.1051/vetres:2003022.

Holmes, M. A., and R. N. Zadoks. 2011. Methicillin resistant S. aureus in human and bovine mastitis. J. Mammary Gland Biol. Neoplasia 16:373-382. https://doi.org/10.1007/s10911-011-9237-x.

Horsburgh, M. J., J. L. Aish, I. J. White, J. K. Lithgow, S. J. Foster, and L. Shaw. 2002. sigmaB modulates virulence determinant expression and stress resistance: Characterization of a functional rsbU strain derived from Staphylococcus aureus 8325-4. J. Bacteriol. 184:5457-5467. https://doi.org/10.1128/JB.184.19.5457.

Hughes, K., and C. J. Watson. 2018. The mammary microenvironment in mastitis in humans, dairy ruminants, rabbits and rodents: A One Health focus. J. Mammary Gland Biol. Neoplasia 23:27-41. https://doi.org/10.1007/s10911-018-9395-1.

Ismail, Z. B. 2017. Mastitis vaccines in dairy cows: Recent developments and recommendations of application. Vet. World 10:10571062. https://doi.org/10.14202/vetworld.2017.1057-1062.

Jenkins, A., A. Diep, T. T. Mai, N. H. Vo, P. Warrener, J. Suzich, C. K. Stover, and R. Sellman. 2015. Differential expression and roles of Staphylococcus aureus virulence determinants during colonization and disease. MBio 6:e2272-e14. https://doi.org/10.1128/ mBio.02272-14.

Jensen, K., J. Günther, R. Talbot, W. Petzl, H. Zerbe, H. J. Schuberth, H. M. Seyfert, and E. J. Glass. 2013. Escherichia coli- and Staphylococcus aureus-induced mastitis differentially modulate transcrip- 
tional responses in neighbouring uninfected bovine mammary gland quarters. BMC Genomics 14:36. https://doi.org/10.1186/ 1471-2164-14-36.

Kahl, B. C., K. Becker, and B. Löffler. 2016. Clinical significance and pathogenesis of staphylococcal small colony variants in persistent infections. Clin. Microbiol. Rev. 29:401-427. https://doi.org/10 .1128/CMR.00069-15.

Kalinka, J., M. Hachmeister, J. Geraci, D. Sordelli, U. Hansen, S. Niemann, S. Oetermann, G. Peters, B. Löffler, and L. Tuchscherr. 2014. Staphylococcus aureus isolates from chronic osteomyelitis are characterized by high host cell invasion and intracellular adaptation, but still induce inflammation. Int. J. Med. Microbiol. https:/ /doi.org/10.1016/j.ijmm.2014.07.013.

Kaparakis-Liaskos, M., and R. L. Ferrero. 2015. Immune modulation by bacterial outer membrane vesicles. Nat. Rev. Immunol. 15:375387. https://doi.org/10.1038/nri3837.

Kovacs-Nolan, J., J. W. Mapletoft, L. Latimer, L. A. Babiuk, and S. V. D. Littel-van den Hurk. 2009. CpG oligonucleotide, host defense peptide and polyphosphazene act synergistically, inducing long-lasting, balanced immune responses in cattle. Vaccine 27:2048-2054. https://doi.org/10.1016/j.vaccine.2009.01.117.

Kriegeskorte, A., S. Grubmüller, C. Huber, B. C. Kahl, C. von Eiff, R. A. Proctor, G. Peters, W. Eisenreich, and K. Becker. 2014. Staphylococcus aureus small colony variants show common metabolic features in central metabolism irrespective of the underlying auxotrophism. Front. Cell. Infect. Microbiol. 4:141. https://doi .org $/ 10.3389 /$ fcimb.2014.00141.

Lacey, K. A., J. M. Leech, S. J. Lalor, N. McCormack, J. A. Geoghegan, and R. M. McLoughlin. 2017. The Staphylococcus aureus cell wall-anchored protein clumping factor $\mathrm{A}$ is an important $\mathrm{T}$ cell antigen. Infect. Immun. 85:1-12. https://doi.org/10.1128/IAI.00549 -17 .

Lammers, A., E. Kruijt, C. Van De Kuijt, P. J. M. Nuijten, and H. E. Smith. 2000. Identification of Staphylococcus aureus genes expressed during growth in milk: A useful model for selection of genes important in bovine mastitis? Microbiology 146:981-987. https://doi.org/10.1099/00221287-146-4-981.

Lanctôt, S., P. Fustier, A. R. Taherian, B. Bisakowski, X. Zhao, and P. Lacasse. 2017. Effect of intramammary infusion of chitosan hydrogels at drying-off on bovine mammary gland involution. J. Dairy Sci. 100:2269-2281. https://doi.org/10.3168/jds.2016-12087.

Landin, H., M. J. Mörk, M. Larsson, and K. P. Waller. 2015. Vaccination against Staphylococcus aureus mastitis in two Swedish dairy herds. Acta Vet. Scand. 57:81. https://doi.org/10.1186/s13028-015 -0171-6.

Le Maréchal, C., N. Seyffert, J. Jardin, D. Hernandez, G. Jan, L. Rault, V. Azevedo, P. François, J. Schrenzel, M. van de Guchte, S. Even, N. Berkova, R. Thiéry, J. R. Fitzgerald, E. Vauto, and Y. Le Loir. 2011. Molecular basis of virulence in Staphylococcus aureus mastitis. PLoS One 6:e27354. https://doi.org/10.1371/ journal.pone.0027354.

Li, L., and X. Zhao. 2018. Characterization of the resistance class 1 integrons in Staphylococcus aureus isolates from milk of lactating dairy cattle in Northwestern China. BMC Vet. Res. 14:59.

Lin, L., A. S. Ibrahim, X. Xu, J. M. Farber, V. Avanesian, B. Baquir, Y. Fu, S. W. French, J. E. Edwards, and B. Spellberg. 2009. Th1Th17 cells mediate protective adaptive immunity against Staphylococcus aureus and Candida albicans infection in mice. PLoS Pathog. 5:e1000703. https://doi.org/10.1371/journal.ppat.1000703.

Löffler, B., L. Tuchscherr, S. Niemann, and G. Peters. 2014. Staphylococcus aureus persistence in non-professional phagocytes. Int. J. Med. Microbiol. https://doi.org/10.1016/j.ijmm.2013.11.011.

Lowe, A. M., D. T. Beattie, and R. L. Deresiewicz. 1998. Identification of novel staphylococcal virulence genes by in vivo expression technology. Mol. Microbiol. 27:967-976. https://doi.org/10.1046/j .1365-2958.1998.00741.x.

Luoreng, Z. M., X. P. Wang, C. G. Mei, and L. Sen Zan. 2018. Comparison of microRNA profiles between bovine mammary glands infected with Staphylococcus aureus and Escherichia coli. Int. J. Biol. Sci. 14:87-99. https://doi.org/10.7150/ijbs.22498.
Middleton, J. R. 2008. Staphylococcus aureus antigens and challenges in vaccine development for humans and dairy cattle. Expert Rev. Vaccines $7: 1-11$.

Middleton, J. R., C. D. Luby, and D. S. Adams. 2009. Efficacy of vaccination against staphylococcal mastitis: A review and new data. Vet. Microbiol. 134:192-198. https://doi.org/10.1016/j.vetmic .2008.09.053.

Misra, N., X. Pu, D. N. Holt, M. A. McGuire, and J. K. Tinker. 2018. Immunoproteomics to identify Staphylococcus aureus antigens expressed in bovine milk during mastitis. J. Dairy Sci. 101:62966309. https://doi.org/10.3168/jds.2017-14040.

Mitchell, G., A. Fugère, K. Pépin Gaudreau, E. Brouillette, E. H. Frost, A. M. Cantin, and F. Malouin. 2013. SigB is a dominant regulator of virulence in Staphylococcus aureus small-colony variants. PLoS One 8:e65018. https://doi.org/10.1371/journal.pone .0065018 .

Mitchell, G., C.-A. Lamontagne, E. Brouillette, G. Grondin, B. G. Talbot, M. Grandbois, and F. Malouin. 2008. Staphylococcus aureus SigB activity promotes a strong fibronectin-bacterium interaction which may sustain host tissue colonization by small-colony variants isolated from cystic fibrosis patients. Mol. Microbiol. 70:15401555. https://doi.org/10.1111/j.1365-2958.2008.06511.x.

Mitchell, G., D. L. Séguin, A. Asselin, E. Déziel, A. M. Cantin, E. H. Frost, S. Michaud, and F. Malouin. 2010. Staphylococcus aureus sigma B-dependent emergence of small-colony variants and biofilm production following exposure to Pseudomonas aeruginosa 4-hydroxy-2-heptylquinoline-N-oxide. BMC Microbiol. 10:33.

Mulhbacher, J., E. Brouillette, M. Allard, L.-C. Fortier, F. Malouin, and D. A. Lafontaine. 2010. Novel riboswitch ligand analogs as selective inhibitors of guanine-related metabolic pathways. PLoS Pathog. 6:e1000865. https://doi.org/10.1371/journal.ppat .1000865 .

Murai, K., T. W. Lehenbauer, J. D. Champagne, K. Glenn, and S. S. Aly. 2014. Cost-effectiveness of diagnostic strategies using quantitative real-time PCR and bacterial culture to identify contagious mastitis cases in large dairy herds. Prev. Vet. Med. 113:522-535. https://doi.org/10.1016/j.prevetmed.2014.01.001.

Naqvi, S. A., J. De Buck, S. Dufour, and H. W. Barkema. 2018. Udder health in Canadian dairy heifers during early lactation. J. Dairy Sci. 101:3233-3247. https://doi.org/10.3168/jds.2017-13579.

Nicholls, E. F., L. Madera, and R. E. W. Hancock. 2010. Immunomodulators as adjuvants for vaccines and antimicrobial therapy Ann. N. Y. Acad. Sci. 1213:46-61. https://doi.org/10.1111/j.1749 $-6632.2010 .05787 . x$.

Novick, R. P., and E. Geisinger. 2008. Quorum sensing in staphylococci. Annu. Rev. Genet. 42:541-564. https://doi.org/10.1146/ annurev.genet.42.110807.091640.

Olde Riekerink, R. G. M., H. W. Barkema, D. F. Kelton, and D. T. Scholl. 2008. Incidence rate of clinical mastitis on Canadian dairy farms. J. Dairy Sci. 91:1366-1377. https://doi.org/10.3168/ jds.2007-0757.

Otto, M. 2013. Staphylococcal infections: Mechanisms of biofilm maturation and detachment as critical determinants of pathogenicity. Annu. Rev. Med. 64:175-188. https://doi.org/10.1146/annurev -med-042711-140023.

Ou, J. J. J., A. J. Drilling, C. Cooksley, A. Bassiouni, S. P. Kidd, A J. Psaltis, P. J. Wormald, and S. Vreugde. 2016. Reduced innate immune response to a Staphylococcus aureus small colony variant compared to its wild-type parent strain. Front. Cell. Infect. Microbiol. 6:187. https://doi.org/10.3389/fcimb.2016.00187.

Oviedo-Boyso, J., J. J. Valdez-Alarcon, M. Cajero-Juarez, A. OchoaZarzosa, J. E. Lopez-Meza, A. Bravo-Patino, and V. M. BaizabalAguirre. 2007. Innate immune response of bovine mammary gland to pathogenic bacteria responsible for mastitis. J. Infect. 54:399409. https://doi.org/10.1016/j.jinf.2006.06.010.

Pader, V., E. H. James, K. L. Painter, S. Wigneshweraraj, and A. M. Edwards. 2014. The Agr quorum-sensing system regulates fibronectin-binding but not hemolysis in the absence of a functional electron transport chain. Infect. Immun. 82:4337-4347. https://doi .org/10.1128/IAI.02254-14. 
Painter, K. L., A. Hall, K. P. Ha, and A. M. Edwards. 2017. The electron transport chain sensitizes Staphylococcus aureus and Enterococcus faecalis to the oxidative burst. Infect. Immun. 85:1-13.

Petrovski, K. R., M. Trajcev, and G. Buneski. 2006. A review of the factors affecting the costs of bovine mastitis. J. S. Afr. Vet. Assoc. $77: 52-60$.

Petzl, W., H. Zerbe, J. Günther, H. M. Seyfert, J. Hussen, and H. J. Schuberth. 2018. Pathogen-specific responses in the bovine udder. Models and immunoprophylactic concepts. Res. Vet. Sci. 116:5561. https://doi.org/10.1016/j.rvsc.2017.12.012.

Pourcel, C., K. Hormigos, L. Onteniente, O. Sakwinska, R. H. Deurenberg, and G. Vergnaud. 2009. Improved MLVA assay for Staphylococcus aureus providing a highly informative genotyping technique together with strong phylogenetic value. J. Clin. Microbiol. 47:3121-3128. https://doi.org/10.1128/JCM.00267-09.

Prenafeta, A., R. March, A. Foix, I. Casals, and L. Costa. 2010. Study of the humoral immunological response after vaccination with a Staphylococcus aureus biofilm-embedded bacterin in dairy cows: possible role of the exopolysaccharide specific antibody production in the protection from Staphylococcus aureus induced mastitis. Vet. Immunol. Immunopathol. 134:208-217. https://doi.org/10.1016/j .vetimm.2009.09.020

Proctor, R. A., C. von Eiff, B. C. Kahl, K. Becker, P. McNamara, M. Herrmann, and G. Peters. 2006. Small colony variants: A pathogenic form of bacteria that facilitates persistent and recurrent infections. Nat. Rev. Microbiol. 4:295-305. https://doi.org/10.1038/ nrmicro1384.

Rainard, P., P. Cunha, S. Bougarn, A. Fromageau, C. Rossignol, F. B. Gilbert, and P. Berthon. 2013. T helper 17-associated cytokines are produced during antigen-specific inflammation in the mammary gland. PLoS One 8:e63471. https://doi.org/10.1371/journal .pone.0063471.

Rainard, P., G. Foucras, J. R. Fitzgerald, J. L. Watts, G. Koop, and J. R. Middleton. 2018. Knowledge gaps and research priorities in Staphylococcus aureus mastitis control. Transbound. Emerg. Dis. 65:149-165. https://doi.org/10.1111/tbed.12698.

Rainard, P., and C. R. Riollet. 2006. Innate immunity of the bovine mammary gland. Vet. Res. 37:369-400. https://doi.org/10.1051/ vetres:2006007.

Reyher, K. K., S. Dufour, H. W. Barkema, L. Des Côteaux, T. J. Devries, I. R. Dohoo, G. P. Keefe, J.-P. Roy, and D. T. Scholl. 2011. The National Cohort of Dairy Farms - A data collection platform for mastitis research in Canada. J. Dairy Sci. 94:16161626. https://doi.org/10.3168/jds.2010-3180.

Roy, J.-P., and G. Keefe. 2012. Systematic review: What is the best antibiotic treatment for Staphylococcus aureus intramammary infection of lactating cows in North America? Vet. Clin. North Am. Food Anim. Pract. 28:39-50. https://doi.org/10.1016/j.cvfa.2011 .12 .004 .

Ruegg, P. L. 2017. A 100-Year Review : Mastitis detection, management, and prevention. J. Dairy Sci. 100:10381-10397. https://doi .org/10.3168/jds.2017-13023.

Sabat, A., J. Krzyszton-russjan, W. Strzalka, R. Filipek, K. Kosowska, W. Hryniewicz, J. Travis, and J. Potempa. 2003. New method for typing Staphylococcus aureus strains: Multiple-locus variablenumber tandem repeat analysis of polymorphism and genetic relationships of clinical isolates. J. Clin. Microbiol. 41:1801. https:// doi.org/10.1128/JCM.41.4.1801

Savelkoul, H. F., V. Ferro, M. Strioga, and V. Schijns. 2015. Choice and design of adjuvants for parenteral and mucosal vaccines. Vaccines (Basel) 3:148-171. https://doi.org/10.3390/vaccines3010148.

Schukken, Y. H., V. Bronzo, C. Locatelli, C. Pollera, N. Rota, A. Casula, F. Testa, L. Scaccabarozzi, R. March, D. Zalduendo, R. Guix, and P. Moroni. 2014. Efficacy of vaccination on Staphylococcus aureus and coagulase-negative staphylococci intramammary infection dynamics in 2 dairy herds. J. Dairy Sci. 97:5250-5264. https: //doi.org/10.3168/jds.2014-8008.

Shim, E. H., R. D. Shanks, and D. E. Morin. 2004. Milk loss and treatment costs associated with two treatment protocols for clinical mastitis in dairy cows. J. Dairy Sci. 87:2702-2708. https://doi .org/10.3168/jds.S0022-0302(04)73397-4.
Singh, R., P. Ray, A. Das, and M. Sharma. 2010. Enhanced production of exopolysaccharide matrix and biofilm by a menadioneauxotrophic Staphylococcus aureus small-colony variant. J. Med. Microbiol. 59:521-527. https://doi.org/10.1099/jmm.0.017046-0.

Spaan, A. N., B. G. J. Surewaard, R. Nijland, and J. A. G. van Strijp. 2013. Neutrophils versus Staphylococcus aureus: A biological tug of war. Annu. Rev. Microbiol. 67:629-650. https://doi.org/10 .1146/annurev-micro-092412-155746.

Spellberg, B., and R. Daum. 2012. Development of a vaccine against Staphylococcus aureus. Semin. Immunopathol. 34:335-348. https:/ /doi.org/10.1007/s00281-011-0293-5.

Ster, C., M. Allard, S. Boulanger, M. Lamontagne Boulet, J. Mulhbacher, D. A. Lafontaine, E. Marsault, P. Lacasse, and F. Malouin. 2013. Experimental treatment of Staphylococcus aureus bovine intramammary infection using a guanine riboswitch ligand analog. J. Dairy Sci. 96:1000-1008. https://doi.org/10.3168/jds.2012-5890.

Ster, C., V. Lebeau, J. Leclerc, A. Fugère, K. A. Veh, J. P. Roy, and F. Malouin. 2017. In vitro antibiotic susceptibility and biofilm production of Staphylococcus aureus isolates recovered from bovine intramammary infections that persisted or not following extended therapies with cephapirin, pirlimycin or ceftiofur. Vet. Res. 48:56. https://doi.org/10.1186/s13567-017-0463-0.

Suriyaphol, G., M. Sarikaputi, and P. Suriyaphol. 2009. Differential responses of cells from human skin keratinocyte and bovine mammary epithelium to attack by pore-forming Staphylococcus aureus alpha-toxin. Comp. Immunol. Microbiol. Infect. Dis. 32:491-502. https://doi.org/10.1016/j.cimid.2008.07.002.

Sutra, L., and B. Poutrel. 1994. Virulence factors involved in the pathogenesis of bovine intramammary infections due to Staphylococcus aureus. J. Med. Microbiol. 40:79-89.

Tan, N. C. W., C. M. Cooksley, E. Roscioli, A. J. Drilling, R. Douglas, P. J. Wormald, and S. Vreugde. 2014. Small-colony variants and phenotype switching of intracellular Staphylococcus aureus in chronic rhinosinusitis. Allergy 69:1364-1371. https://doi.org/10 $.1111 /$ all.12457.

Taverna, F., A. Negri, R. Piccinini, A. Zecconi, S. Nonnis, S. Ronchi, and G. Tedeschi. 2007. Characterization of cell wall associated proteins of a Staphylococcus aureus isolated from bovine mastitis case by a proteomic approach. Vet. Microbiol. 119:240-247. https: //doi.org/10.1016/j.vetmic.2006.09.007.

Tollersrud, T., A. H. Kampen, and K. Kenny. 2006. Staphylococcus aureus enterotoxin D is secreted in milk and stimulates specific antibody responses in cows in the course of experimental intramammary infection. Infect. Immun. 74:3507-3512. https://doi.org/10 .1128/IAI.01726-05.

Tuchscherr, L., E. Medina, M. Hussain, W. Völker, V. Heitmann, S. Niemann, D. Holzinger, J. Roth, R. A. Proctor, K. Becker, G. Peters, and B. Löffler. 2011. Staphylococcus aureus phenotype switching: an effective bacterial strategy to escape host immune response and establish a chronic infection. EMBO Mol. Med. 3:129-141. https://doi.org/10.1002/emmm.201000115.

Vaudaux, P., E. Huggler, W. Rhys-Williams, W. G. Love, and D. P. Lew. 2011. Extracellular and intracellular bactericidal activities of XF-70 against small-colony variant hemB mutants of meticillin-susceptible and meticillin-resistant Staphylococcus aureus. Int. J. Antimicrob. Agents 37:576-579. https://doi.org/10.1016/ j.ijantimicag.2011.01.015.

Veh, K. A., R. C. Klein, C. Ster, G. Keefe, P. Lacasse, D. Scholl, J.-P. J.-P. Roy, D. Haine, S. Dufour, B. G. Talbot, A. O. B. Ribon, and F. Malouin. 2015. Genotypic and phenotypic characterization of Staphylococcus aureus causing persistent and nonpersistent subclinical bovine intramammary infections during lactation or the dry period. J. Dairy Sci. 98:155-168. https://doi.org/10.3168/jds .2014-8044.

Vrieling, M., E. M. Boerhout, G. F. van Wigcheren, K. J. Koymans, T. G. Mols-Vorstermans, C. J. C. de Haas, P. C. Aerts, I. J. J. M. Daemen, K. P. M. van Kessel, A. P. Koets, V. P. M. G. Rutten, P. J. M. Nuijten, J. A. G. van Strijp, and L. Benedictus. 2016. LukMF' is the major secreted leukocidin of bovine Staphylococcus aureus and is produced in vivo during bovine mastitis. Sci. Rep. 6:37759. https://doi.org/10.1038/srep37759. 
Vrieling, M., K. J. Koymans, D. A. Heesterbeek, P. C. Aerts, V. P. Rutten, C. J. de Haas, K. P. van Kessel, A. P. Koets, R. Nijland, and J. A. van Strijp. 2015. Bovine Staphylococcus aureus secretes the leukocidin LukMF' to kill migrating neutrophils through CCR1. MBio 6:e00335. https://doi.org/10.1128/mBio.00335-15.

Wang, S.-C., C.-M. Wu, S.-C. Xia, Y.-H. Qi, L.-N. Xia, and J.-Z. Shen. 2009. Distribution of superantigenic toxin genes in Staphylococcus aureus isolates from milk samples of bovine subclinical mastitis cases in two major diary production regions of China. Vet. Microbiol. 137:276-281. https://doi.org/10.1016/j.vetmic.2009.01.007.

Wilson, G. J., S. W. Tuffs, B. A. Wee, K. S. Seo, N. Park, T. Connelley, C. M. Guinane, W. I. Morrison, and J. R. Fitzgerald. 2018. Bovine Staphylococcus aureus superantigens stimulate the entire T cell repertoire of cattle. Infect. Immun. 86:IAI.00505-18. https:// doi.org/10.1128/IAI.00505-18.

Yagci, S., G. Hascelik, D. Dogru, U. Ozcelik, and B. Sener. 2013. Prevalence and genetic diversity of Staphylococcus aureus small- colony variants in cystic fibrosis patients. Clin. Microbiol. Infect. 19:77-84. https://doi.org/10.1111/j.1469-0691.2011.03742.x.

Yang, D., A. R. Wijenayaka, L. B. Solomon, S. M. Pederson, D. M. Findlay, S. P. Kidd, and G. J. Atkins. 2018. Novel insights into Staphylococcus aureus deep bone infections: The involvement of osteocytes. MBio 9:1-10. https://doi.org/10.1128/mBio.00415-18.

Zadoks, R. N., J. R. Middleton, S. McDougall, J. Katholm, and Y. H. Schukken. 2011. Molecular epidemiology of mastitis pathogens of dairy cattle and comparative relevance to humans. J. Mammary Gland Biol. Neoplasia 16:357-372. https://doi.org/10.1007/s10911 $-011-9236-\mathrm{y}$

Zheng, S. Y., B. Yu, K. Zhang, M. Chen, Y. H. Hua, S. Yuan, R. M. Watt, B. J. Zheng, K. Y. Yuen, and J. D. Huang. 2012. Comparative immunological evaluation of recombinant Salmonella Typhimurium strains expressing model antigens as live oral vaccines. BMC Immunol. 13:54. https://doi.org/10.1186/1471-2172-13-54. 